\title{
NFAT5 wt Allele
}

National Cancer Institute

\section{Source}

National Cancer Institute. NFAT5 wt Allele. NCI Thesaurus. Code C93132.

Human NFAT 5 wild-type allele is located in the vicinity of $16 \mathrm{q} 22.1$ and is approximately $140 \mathrm{~kb}$ in length. This allele, which encodes nuclear factor of activated T-cells 5 protein, plays a role in the regulation of transcription of osmotic stress responsive genes. 